\title{
The Emilia 2012 sequence: a macroseismic survey
}

\author{
Andrea Tertulliani ${ }^{1,{ }^{\star}}$, Luca Arcoraci ${ }^{2}$, Michele Berardi ${ }^{2}$, Filippo Bernardini ${ }^{3}$, Beatriz Brizuela ${ }^{4}$, \\ Corrado Castellano ${ }^{2}$, Sergio Del Mese ${ }^{2}$, Emanuela Ercolani ${ }^{3}$, Laura Graziani ${ }^{4}$, Alessandra Maramai ${ }^{4}$, \\ Antonio Rossi ${ }^{2}$, Manuela Sbarra ${ }^{1}$, Maurizio Vecchi ${ }^{1}$
}

\author{
${ }^{1}$ Istituto Nazionale di Geofisica e Vulcanologia, Sezione Roma 1, Roma, Italy \\ ${ }^{2}$ Istituto Nazionale di Geofisica e Vulcanologia, Centro Nazionale Terremoti, Roma, Italy \\ ${ }^{3}$ Istituto Nazionale di Geofisica e Vulcanologia, Sezione di Bologna, Bologna, Italy \\ ${ }^{4}$ Istituto Nazionale di Geofisica e Vulcanologia, Sezione Roma 2, Roma, Italy
}

\section{Article history}

Received July 23, 2012; accepted August 31, 2012.

Subject classification:

Surveys, measurements and monitoring, Macroseismics.

\section{Introduction}

On May 20, 2012, at 4:03 local time (2:03 UTC), a large part of the Po Valley between the cities of Ferrara, Modena and Mantova was struck by a damaging earthquake $\left(M_{L}\right.$ 5.9). The epicenter was located by the Istituto Nazionale di Geofisica e Vulcanologia (INGV) seismic network [ISIDe 2010] at $44.889^{\circ} \mathrm{N}$ and $11.228^{\circ} \mathrm{E}$, approximately $30 \mathrm{~km}$ west of Ferrara (Figure 1 ).

The event was preceded by a foreshock that occurred at 01:13 local time, with a magnitude of $M_{L} 4$. The mainshock started an intense seismic sequence that lasted for weeks, counting more than 2,000 events, six of which had $M_{L}>5$. The strongest earthquakes of this sequence occurred on May 29, 2012, with $M_{L} 5.8$ and $M_{L} 5.3$, recorded at 9:00 and 12:55 local time, respectively. The epicenters of the May 29, 2012, events were located at the westernmost part of the rupture zone of the May 20, 2012, earthquake (Figure 2).

The May 20 and 29, 2012, earthquakes were felt through the whole of northern and central Italy, and as far as Switzerland, Slovenia, Croatia, Austria, south-eastern France and southern Germany.

Historical information reveals that the seismic activity in the Po Valley is moderate; indeed, except for the event that struck Ferrara on November 17, 1570, the last version of the Parametric Catalogue of Italian Earthquakes (CPTI11) [Rovida et al. 2011] does not report many other significant earthquakes occurring in this area [see also Castelli et al. 2012, this volume].

At times, small-to-medium-magnitude earthquakes have occurred in the area of the 2012 sequence, such as the events of December 6, $1986\left(\mathrm{M}_{\mathrm{W}} 4.6\right)$, and May 2 and 8, $1987\left(\mathrm{M}_{\mathrm{W}} 4.7\right.$, 4.6, respectively), that struck the northern sector of the Modena Province [Locati et al. 2011, Rovida et al. 2011].

The Po Valley is also affected by more frequent seismic activity due to the interaction of the northern Apennines and the Piedmont belt of Emilia, between Parma and Modena, where events of moderate magnitude often occur. An example of this seismicity was the October 15, 1996, Correggio (Reggio-Emilia) earthquake [Rovida et al. 2011]: this $\mathrm{M}_{\mathrm{W}} 5.4$ event produced effects that extended up to the most damaged areas of the 2012 sequence [Locati et al. 2011]

Soon after the strong earthquake occurred on May 20, 2012, the INGV 'QUick Earthquake Survey Team' (QUEST) organized a field survey of the major damaged areas, to be able to assign macroseismic intensities according to the European Macroseismic Scale (EMS98) [Grünthal 1998].

To take into account the cumulative effects of the aftershocks and their westward displacements, the survey was continuously adjusted and updated, to follow the enlarging 'most damaged zone'. In this report, the preliminary results of the macroseismic survey are presented.

\section{The macroseismic survey methodology}

The field survey performed in the most damaged zones followed the macroseismic techniques commonly used by the INGV: the assessment of the intensity is based on the damage observed to the residential building stock and on the perception of the effects noticed or experienced by people during the earthquake. The buildings observed were divided into typologies and then into vulnerability classes, on the basis of their characteristics. With this aim, the QUEST team performed detailed surveys of the current state of the building stock, to assess the grade of damage according to the EMS98 scale [Grünthal 1998]. The most common building typologies observed in the surveyed area were old traditional brick houses, and recent residential buildings in brick or reinforced concrete. Old traditional brick houses are in the his- 


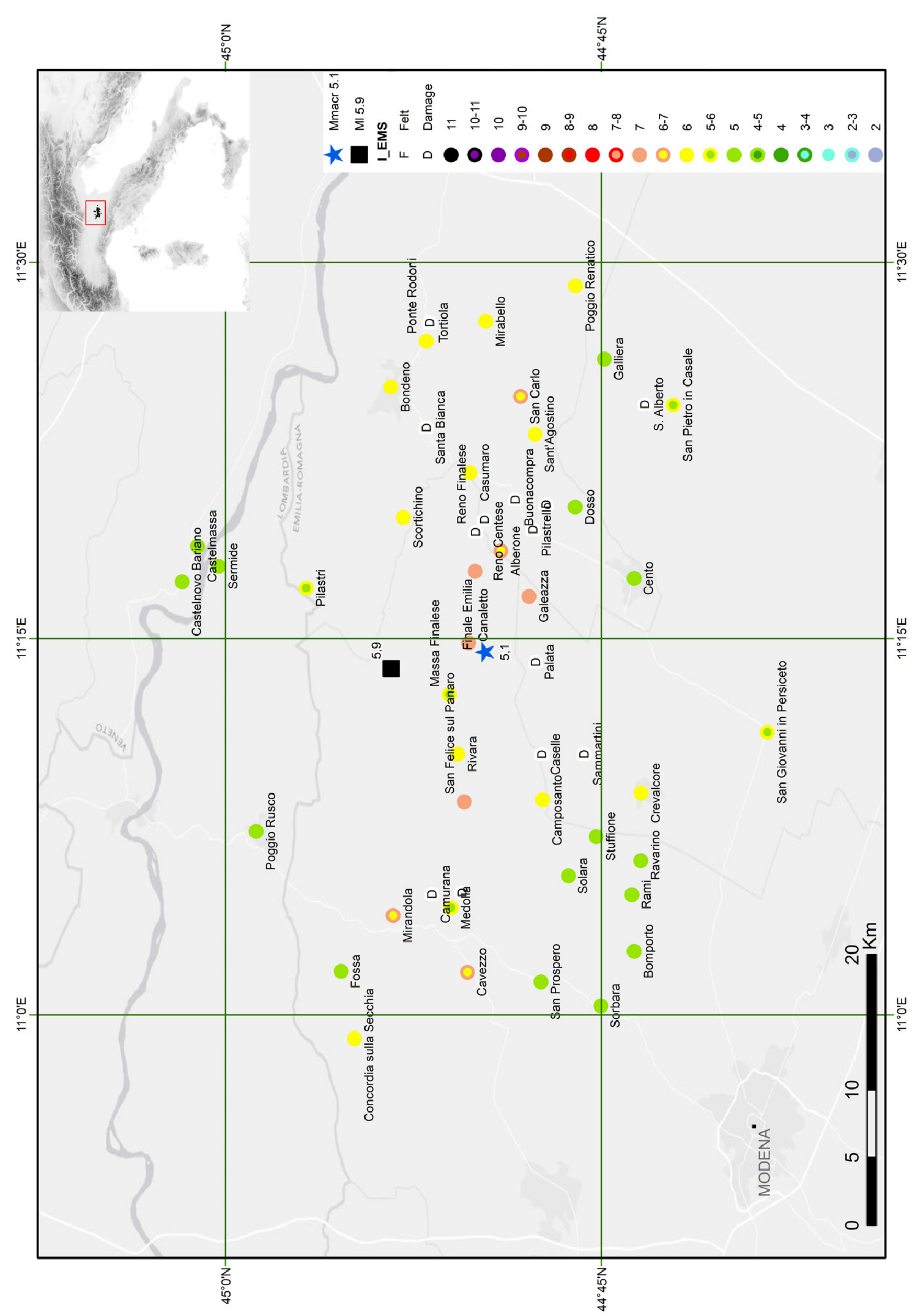




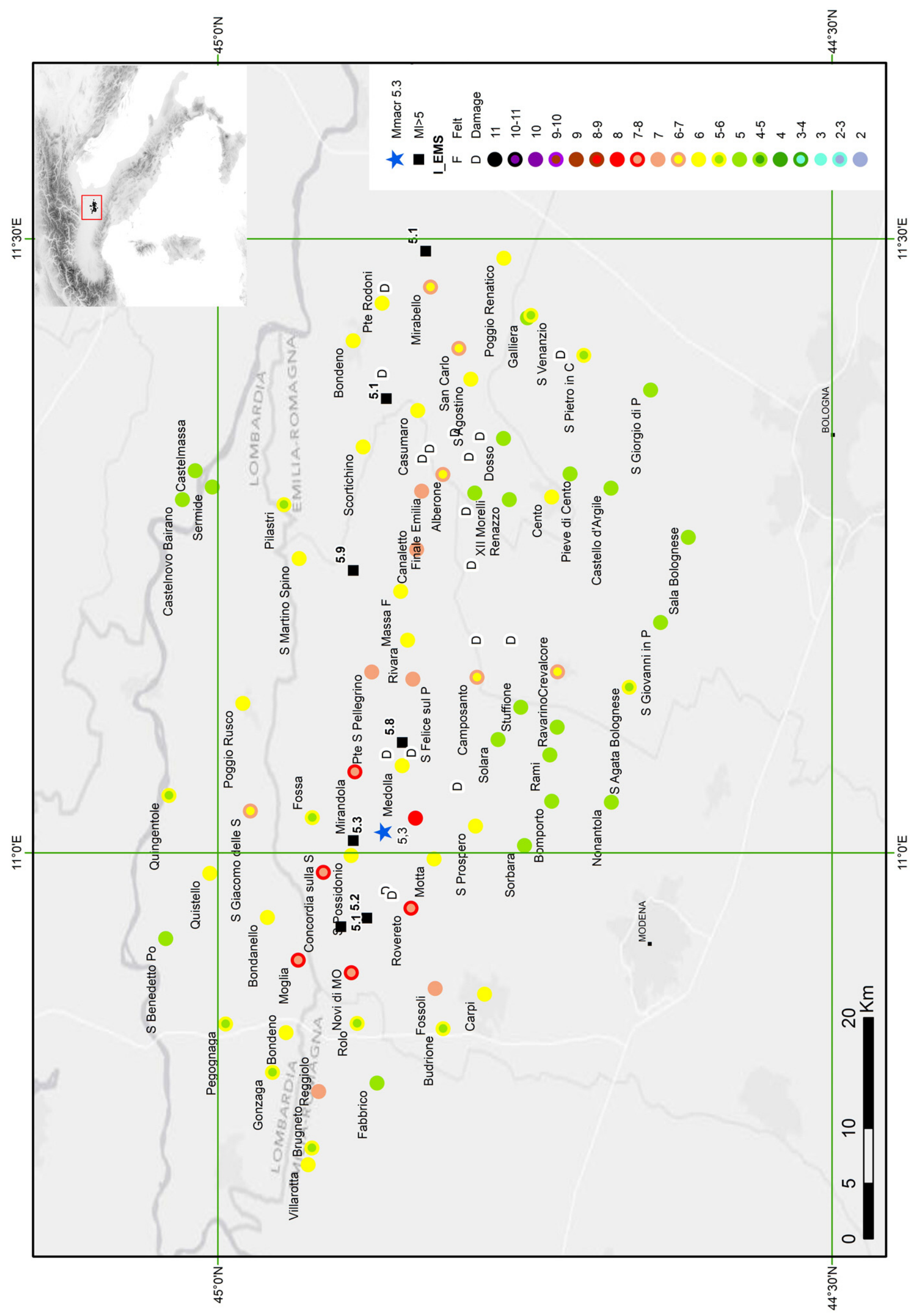


toric centers, and often lack connections or reinforcing elements, like tie rods or buttresses (vulnerability classes A or B were assigned, according to their state of maintenance). Such reinforcing elements are commonly found in other Italian areas that are prone to significant seismic activity, but they appear not to belong to the building tradition in this study area, even for historical mansions.

The recent one-or-two-story residential dwellings in brick or reinforced concrete are mainly sited on the outskirts of the villages and towns (vulnerability classes B and C). The latter type is more common than the traditional brick buildings. Industrial warehouses and numerous farmhouses were also observed through the countryside or in the suburbs of the towns and cities visited. Industrial warehouses are isolated from inhabited areas, and following the guidelines of the EMS98 scale, they were not considered as representative for the intensity value assessment, as for other special buildings like monuments, churches, towers and belfries. Nevertheless, to have a more complete picture of the effects of the 2012 sequence, the damage observed on special buildings and farmhouses was reported as well, as this kind of information is useful to give a thorough picture of the damage distribution, especially in the localities where the residential building stock was undamaged or only lightly damaged.

Widespread damage to chimneys was observed during the survey, both for masonry (vulnerability class B) and reinforced-concrete (vulnerability class $\mathrm{C}$ ) buildings. This peculiarity led us to make a methodological choice. According to the EMS98 scale, the failure of chimneys is considered diagnostic of grade 3 damage ("moderate structural damage or heavy non-structural damage") for masonry buildings. However, the field survey demonstrated that this type of damage was accompanied by hardly any other diagnostic elements of similar severity. Indeed, in most cases, the failure of the chimney in masonry houses was accompanied by grade 2 damage diagnostics, or was even the only damage observed. This behavior induced us to 'downgrade' the failure of chim- neys in masonry houses to be diagnostic of grade 2 damage. For reinforced-concrete buildings, the EMS98 does not assess this kind of damage at all. To take this indicator into account, which was often observed, chimney failure on reinforcedconcrete buildings was defined as diagnostic of grade 1 . This assumption was supported because frequently this was indeed the only noticeable effect of the shaking on reinforcedconcrete buildings, which was observed even before the appearance of fine cracks in the plaster. Given the preliminary nature of this study, this interesting issue cannot be stressed here, but will be the object of further studies.

The intensity values assigned as a result of the field survey represent the cumulative effects of the May-June 2012 sequence, as it was almost impossible to distinguish the damage caused by every single strong earthquake after the May 29, 2012, aftershocks, although the survey was continuously updated.

Anyway, through the prompt reaction, it was possible to define the intensity distribution for the May 20, 2012, event in about 50 localities, which were surveyed before the occurrence of the important aftershocks [see also QUESTINGV 2012].

\section{Intensity assessment}

After the May 20, 2012, earthquake, the maximum intensity value (7 EMS98) was assigned to three localities (see Table 1, $\mathrm{I}_{\mathrm{EMS}}$ 20/05 column; and Figure 1). Major damage (a limited number of total collapses and many partial collapses) was observed in the old and monumental buildings in the historical centers (Figure 3a). Class A and B buildings suffered widespread cracks in the walls, detachment of tiles, and chimney falls (Figure 3b). Heavy damage to industrial bays and farmhouses, and also the collapse of numerous barns, was observed through the whole epicentral area. Almost everywhere in the epicentral area churches, belfries and city towers were heavily damaged, if not collapsed. Minor damage to reinforced-concrete buildings was observed in a few
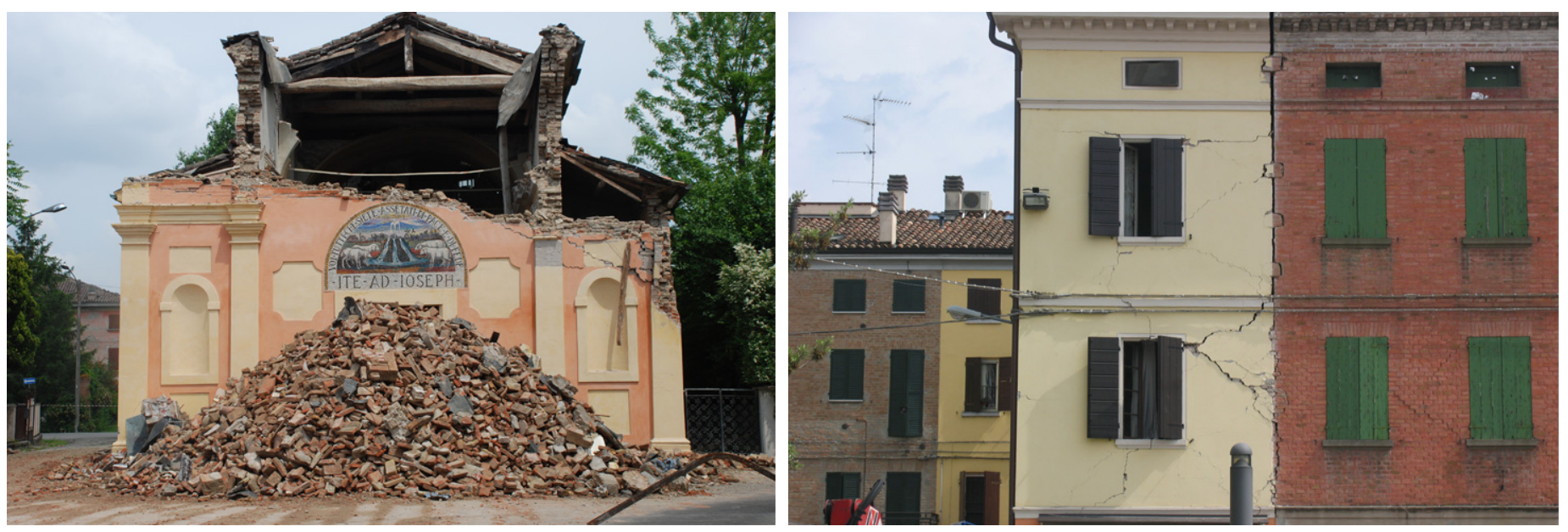

Figure 3. a. Partial collapse of a monumental building: the S. Giuseppe church in San Felice sul Panaro. b. Widespread cracks in a class B building in Cavezzo. 
cases. Many localities showed slight damage, as generally non-structural or light structural damage. Nevertheless, in other localities, more severe effects produced by the earthquakes were observed, even if sporadically; in these localities, intensity values of 6 and 6-7 were assessed. Intensity 5 and 5-6 were assigned to all those villages where the damage was negligible or occasionally observed, and in any case where it was very slight.

As a consequence of the occurrence of the large aftershocks on May 29, 2012, the QUEST team performed a new field survey to update the information previously collected. All of the localities already visited were surveyed again, and many others were visited for the first time. The aftershocks were located westwards with respect to the mainshock, and they caused heavy damage in a new, larger area, which partially overlapped the maximum effects area struck by the May 20, 2012, event.

The new survey continued during the whole month of June, gathering data from about 90 localities. The final intensities represent the cumulative effects due to the whole sequence. The highest intensity values (I $>7$ EMS98) were assigned to six localities (Table 1), where a few collapses were observed, both in buildings of reinforced concrete (vulnerability class $\mathrm{C}$ ) and masonry (vulnerability classes A and B).

In these localities, many buildings suffered heavy damage, such as large and extensive cracks, failure of walls and roofs, and extensive falling of chimneys and roof tiles. In some cases, partial collapse was also observed (grade 4). Reinforced-concrete buildings rarely suffered structural damage, like cracks in beams and columns, and more extensive cracks in partition walls. There was total collapse of very few reinforced-concrete buildings at Cavezzo $(I=8)$, which had already been slightly damaged by the mainshock (Figure 4), whereas at Rovereto sulla Secchia, several recent residential buildings suffered partial collapse. Mirandola, Concordia sulla Secchia and Moglia showed widespread substantial-to-heavy damage, especially concentrated in the his- torical centers, and mainly characterized by buildings of vulnerability classes A and B. Also in these cases, total collapse was very rare. Intensity values sharply increased for Mirandola, Concordia and Cavezzo after the May 29, 2012, aftershocks (see Table 1).

Intensity values as high as 7 were assigned to six localities, where a large number of masonry buildings of vulnerability classes A and B suffered moderate damage, as grades 2 and 3 , such as large cracks in walls and the falling of chimneys and roof-tiles. On the contrary, the damage to reinforced-concrete buildings was light. Nevertheless, a few collapses and heavily damaged monuments and old scruffy structures were observed in the historical centers (usually smaller than the most recent built areas) of localities like San Felice sul Panaro and Finale Emilia.

Twenty six localities were assessed at 6 and 6-7 intensities. In these cases, the damage observed was moderate and usually occurred to old and vulnerable buildings; damage grade 4 was observed only sporadically. The damage levels at localities like Camposanto, Crevalcore and Mirabello were noticeably larger after the shocks that occurred on May 29, 2012. Special attention should be focused on the village of San Carlo (Sant'Agostino), where the damage observed (corresponding in some cases to damage level 3) was largely caused by relevant liquefaction effects.

In 32 localities, the damage observed was either slight or negligible, which resulted in intensity values of 5 or 5-6. In these cases, the damage reported was usually falling chimneys and small pieces of plaster, but it was not widespread through the whole building stock.

Some of the surveyed settlements were indeed very small, about 50-60 buildings. In these cases, as suggested by the EMS98 scale, any value of intensity assigned would have been unreliable. Nevertheless, the QUEST team chose to assign a ' $\mathrm{D}$ ' (damage) label to these localities, not only to provide useful information gathered during the survey, but also to account for some damage that in many cases was noticeable.
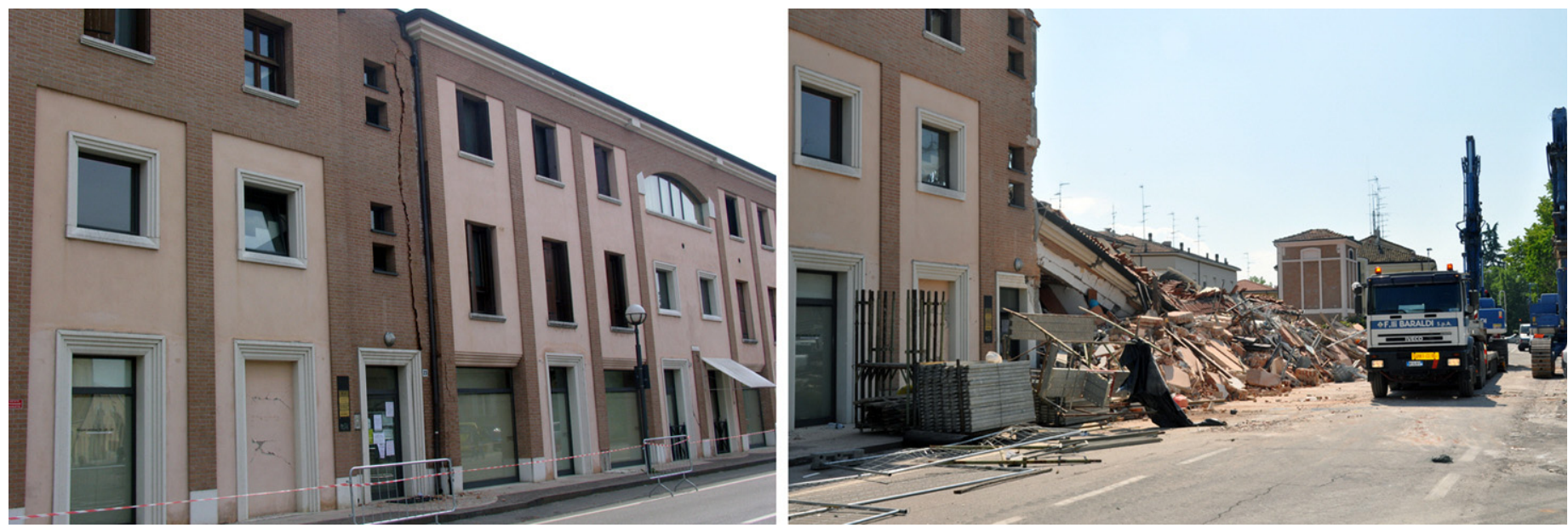

Figure 4. Increase in the damage to reinforced-concrete buildings, for May 20, 2012 (left), and May 29, 2012 (right), in Cavezzo. 
TERTULLIANI ET AL.

\begin{tabular}{|c|c|c|c|c|}
\hline Locality & Municipality & Province & $\mathrm{I}_{\mathrm{EMS}}$ May 20, 2012 & Final $\mathrm{I}_{\mathrm{EMS}}$ \\
\hline Cavezzo & & $\mathrm{MO}$ & $6-7$ & 8 \\
\hline Concordia sulla Secchia & & $\mathrm{MO}$ & 6 & $7-8$ \\
\hline Mirandola & & MO & $6-7$ & $7-8$ \\
\hline Moglia & & $\mathrm{MN}$ & & $7-8$ \\
\hline Novi di Modena & & $\mathrm{MO}$ & & $7-8$ \\
\hline Rovereto sulla Secchia & Carpi & $\mathrm{MO}$ & & $7-8$ \\
\hline Canaletto & Finale Emilia & $\mathrm{MO}$ & 7 & 7 \\
\hline Finale Emilia & & $\mathrm{MO}$ & 7 & 7 \\
\hline Fossoli & Carpi & $\mathrm{MO}$ & & 7 \\
\hline Ponte San Pellegrino & Mirandola & $\mathrm{MO}$ & & 7 \\
\hline Reggiolo & & $\mathrm{RE}$ & & 7 \\
\hline San Felice sul Panaro & & $\mathrm{MO}$ & 7 & 7 \\
\hline Alberone & Cento & $\mathrm{FE}$ & $6-7$ & $6-7$ \\
\hline Camposanto & & $\mathrm{MO}$ & 6 & $6-7$ \\
\hline Crevalcore & & $\mathrm{BO}$ & 6 & $6-7$ \\
\hline Mirabello & & $\mathrm{FE}$ & 6 & $6-7$ \\
\hline San Carlo & Sant'Agostino & FE & $6-7$ & $6-7$ \\
\hline San Giacomo delle Segnate & & $\mathrm{MN}$ & & $6-7$ \\
\hline Bondanello & Moglia & $\mathrm{MN}$ & & 6 \\
\hline Bondeno & & $\mathrm{FE}$ & 6 & 6 \\
\hline Bondeno & Gonzaga & $\mathrm{MN}$ & & 6 \\
\hline Carpi & & $\mathrm{MO}$ & & 6 \\
\hline Casumaro & Bondeno & $\mathrm{FE}$ & 6 & 6 \\
\hline Cento & & FE & 5 & 6 \\
\hline Massa Finalese & Finale Emilia & $\mathrm{MO}$ & $5-6$ & 6 \\
\hline Medolla & & $\mathrm{MO}$ & $5-6$ & 6 \\
\hline Motta & Cavezzo & $\mathrm{MO}$ & & 6 \\
\hline Poggio Renatico & & $\mathrm{FE}$ & 6 & 6 \\
\hline Poggio Rusco & & $\mathrm{MN}$ & 5 & 6 \\
\hline Ponte Rodoni & Bondeno & $\mathrm{FE}$ & 6 & 6 \\
\hline Quistello & & $\mathrm{MN}$ & & 6 \\
\hline Rivara & San Felice sul Panaro & $\mathrm{MO}$ & 6 & 6 \\
\hline San Martino Spino & Mirandola & $\mathrm{MO}$ & & 6 \\
\hline San Possidonio & & $\mathrm{MO}$ & & 6 \\
\hline San Prospero & & MO & 5 & 6 \\
\hline Sant'Agostino & & $\mathrm{FE}$ & 6 & 6 \\
\hline Scortichino & Bondeno & FE & 6 & 6 \\
\hline Villarotta & Luzzara & $\mathrm{RE}$ & & 6 \\
\hline Buonacompra & Cento & $\mathrm{FE}$ & $\mathrm{D}$ & D \\
\hline Camurana & Medolla & $\mathrm{MO}$ & $\mathrm{D}$ & D \\
\hline Caselle & Crevalcore & $\mathrm{BO}$ & $\mathrm{D}$ & $\mathbf{D}$ \\
\hline Forcello & San Possidonio & MO & & D \\
\hline Galeazza & Crevalcore & $\mathrm{BO}$ & 7 & D \\
\hline Malcantone di Medolla & Medolla & MO & $\mathrm{D}$ & D \\
\hline
\end{tabular}




\begin{tabular}{|c|c|c|c|c|}
\hline Locality & Municipality & Province & I $_{\text {EMS }}$ May 20, 2012 & Final $I_{\text {EMS }}$ \\
\hline Molino Albergati & Cento & $\mathrm{FE}$ & $\mathrm{D}$ & D \\
\hline Palata & Crevalcore & $\mathrm{BO}$ & $\mathrm{D}$ & D \\
\hline Pilastrello & Cento & FE & $\mathrm{D}$ & D \\
\hline Pioppa & San Possidonio & $\mathrm{MO}$ & & D \\
\hline Reno Centese & Cento & $\mathrm{FE}$ & $\mathrm{D}$ & D \\
\hline Reno Finalese & Finale Emilia & $\mathrm{MO}$ & $\mathrm{D}$ & D \\
\hline Sammartini & Crevalcore & BO & $\mathrm{D}$ & D \\
\hline Santa Bianca & Bondeno & $\mathrm{FE}$ & $\mathrm{D}$ & D \\
\hline Sant'Alberto & San Pietro in Casale & BO & $\mathrm{D}$ & D \\
\hline Staggia & San Prospero & $\mathrm{MO}$ & & D \\
\hline Tortiola & Vigarano Mainarda & $\mathrm{FE}$ & $\mathrm{D}$ & D \\
\hline Brugneto & Reggiolo & $\mathrm{RE}$ & & $5-6$ \\
\hline Budrione & Carpi & $\mathrm{MO}$ & & $5-6$ \\
\hline Fossa & Concordia sulla Secchia & $\mathrm{MO}$ & 5 & $5-6$ \\
\hline Gonzaga & & MN & & $5-6$ \\
\hline Pegognaga & & MN & 5 & $5-6$ \\
\hline Pilastri & Bondeno & FE & $5-6$ & $5-6$ \\
\hline Quingentole & & $\mathrm{MN}$ & & $5-6$ \\
\hline Rolo & & $\mathrm{RE}$ & & $5-6$ \\
\hline San Pietro in Casale & & BO & $5-6$ & $5-6$ \\
\hline Sant'Agata Bolognese & & $\mathrm{BO}$ & & $5-6$ \\
\hline San Venanzio & Galliera & $\mathrm{BO}$ & & $5-6$ \\
\hline Bomporto & & $\mathrm{MO}$ & 5 & 5 \\
\hline Castello d'Argile & & $\mathrm{BO}$ & & 5 \\
\hline Castelmassa & & RO & 5 & 5 \\
\hline Castelnovo Bairano & & RO & 5 & 5 \\
\hline Dodici Morelli & Cento & FE & & 5 \\
\hline Dosso & Sant'Agostino & $\mathrm{FE}$ & 5 & 5 \\
\hline Fabbrico & & $\mathrm{RE}$ & & 5 \\
\hline Galliera & & BO & 5 & 5 \\
\hline Nonantola & & $\mathrm{MO}$ & & 5 \\
\hline Pieve di Cento & & FE & & 5 \\
\hline Rami & Ravarino & $\mathrm{MO}$ & 5 & 5 \\
\hline Ravarino & & $\mathrm{MO}$ & 5 & 5 \\
\hline Renazzo & Cento & $\mathrm{FE}$ & & 5 \\
\hline Sala Bolognese & & BO & & 5 \\
\hline San Benedetto Po & & MN & & 5 \\
\hline San Giorgio di Piano & & BO & & 5 \\
\hline San Giovanni in Persiceto & & BO & 5 & 5 \\
\hline Sermide & & MN & 5 & 5 \\
\hline Solara & Bomporto & $\mathrm{MO}$ & 5 & 5 \\
\hline Sorbara & Bomporto & $\mathrm{MO}$ & 5 & 5 \\
\hline Stuffione & Ravarino & MO & 5 & 5 \\
\hline
\end{tabular}

Table 1. Localities surveyed after the May-June 2012 seismic sequence. The data related to the May 20, 2012, are in the fourth column. 


\begin{tabular}{|c|c|c|c|c|}
\hline \multirow[t]{2}{*}{ Event } & \multicolumn{2}{|c|}{ Instrumental parameters } & \multicolumn{2}{|c|}{ Macroseismic parameters } \\
\hline & $\begin{array}{l}\text { Coordinates } \\
\left({ }^{\circ} \mathrm{N} ;{ }^{\circ} \mathrm{E}\right)\end{array}$ & $\mathbf{M}_{\mathbf{L}}$ & $\begin{array}{l}\text { Coordinates } \\
\left({ }^{\circ} \mathrm{N} ;{ }^{\circ} \mathrm{E}\right)\end{array}$ & $\mathbf{M}_{\mathrm{EW}}$ \\
\hline May 20, 2012 & $44.889 ; 11.228$ & 5.9 & $44.828 ; 11.241$ & 5.1 \\
\hline May 29, 2012 & $44.851 ; 11.086$ & 5.8 & - & - \\
\hline Cumulated & - & - & $44.866 ; 11.017$ & 5.3 \\
\hline
\end{tabular}

Table 2. Instrumental parameters [ISIDe 2010] of the May 20 and 29, 2012, earthquakes, and the macroseismic parameters based on the May 20, 2012, intensities and the cumulative intensities computed by Boxer 4.0 [Gasperini et al. 2010].

\section{Macroseismic parameters}

At the end of the survey, as a test, we tried to infer the macroseismic parameters (epicenter and macroseismic magnitude, for the sake of clarity $\mathrm{M}_{\mathrm{EW}}$ hereinafter) from the EMS intensities assessed through the Boxer 4.0 code [Gasperini et al. 2010]. Although we are well aware that the Boxer code was developed and calibrated on the basis of the Mercalli-Cancani-Sieberg (MCS) scale [MCS 1930], we still believe that this non-conventional exercise is worthwhile, to improve the macroseismic practice and to open a discussion on future developments of such kinds of codes.

The $\mathrm{M}_{\mathrm{W}} 5.9$ earthquake of May 20, 2012, produced effects of intensity EMS 7. This value is surprisingly low, considering the more recent empirical relationships for Italy [see Pasolini et al. 2008, Gasperini and Ferrari 2000]. In addition, at the end of the whole sequence, considering the cumulative effects of the seven $M>5$ earthquakes, a maximum intensity value of 8 was assigned to only one locality. It is not surprising then that the macroseismic magnitude of the mainshock $\left(M_{E W} 5.1\right)$ and the macroseismic magnitude based on the cumulative intensity $\left(\mathrm{M}_{\mathrm{EW}} 5.3\right)$ are significantly lower than the instrumental one $\left(\mathrm{M}_{\mathrm{W}}\right.$ 5.9) (Table 2).

Regarding the macroseismic epicenters, the epicenter of the May 20, 2012, earthquake was located slightly to the south of the instrumental one (Figure 1), whereas the barycentre of the cumulated effects was located within the cluster of the largest aftershock that occurred on May 29, 2012, and on June 3, 2012 (Figure 2).

\section{Conclusions}

The field observations and some of the preliminary results can be summarized as follows:

- In general, recent residential building stock did not suffer much damage; heavier damage was observed within the historical centers.

- Most of the total or near total collapses (damage grade 5) involved both special and monumental buildings: industrial warehouses, farmhouses, barns, churches, towers or belfries. These kinds of buildings showed an intrinsic weakness with respect to the seismic ground shaking. A limited number of collapses were seen for the residential build- ing stock. In some places, the investigation revealed occasional very severe damage within a slight damage scenario, which induced very wary assessments, to avoid overestimation of the intensities.

- The aftershocks of May 29, 2012, appeared to affect the residential building stock more severely than the May 20, 2012, event did. It has to be underlined that the May 29, 2012, aftershocks were located close to inhabited areas, while the May 20, 2012, earthquake was located in a relatively remote area.

- The maximum intensity value $\left(\mathrm{I}_{\mathrm{EMS}}\right)$ for the whole sequence is 8 . This value represents the cumulative damage in the area, and it well describes the increase in the damage severity after the May 29, 2012, earthquakes (Figure 2). These earthquakes resulted in the shift of the major damage area westwards.

- The results show that the estimation of the macroseismic magnitudes computed on the basis of the assessed intensity values, was, as expected, considerably lower than the instrumental one (Table 2, Figures 1, 2).

- The intensity maps suggest a marked attenuation of the shaking in the N-S direction, which is noticeable both for the May 20, 2012, event and the cumulative intensity map (Figures 1, 2).

- The heavy damage suffered by many vulnerable buildings, such as farmhouses, barns and industrial warehouses, that was observed at the outskirts of several localities highlights the importance of defining and complying with seismic design codes and specifications, which would have made these types of buildings safer.

Acknowledgements. We thank C.H. Caracciolo, V. Castelli, A. Cavaliere, A. Massucci, R. Tonini and S. Vecchi for their contributions during the field surveys. We also thank Ina Cecic and an anonymous referee for their helpful suggestions.

\section{References}

Castelli, V., F. Bernardini, R. Camassi, C.H. Caracciolo, E. Ercolani and L. Postpischl (2012). Looking for missing earthquake traces in the Ferrara-Modena plain: an update on historical seismicity, Annals of Geophysics, 55 (4); doi:10.4401/ag-6110. 
Gasperini, P., and Ferrari G. (2000). Deriving numerical estimates from descriptive information: the estimation of earthquake synthetic parameters, Annali di Geofisica, 43 (4), 729-746; doi:10.4401/ag-3670.

Gasperini, P., G. Vannucci, D. Tripone and E. Boschi (2010). The location and sizing of historical earthquakes using the attenuation of macroseismic intensity with distance, B. Seismol. Soc. Am., 100, 2035-2066; doi: 10.1785/01200 90330.

Grünthal, G., ed. (1998). European Macroseismic Scale 1998 (EMS-98). European Seismological Commission, Subcommission on Engineering Seismology, Working Group Macroseismic Scales. Conseil de l'Europe, Cahiers du Centre Européen de Géodynamique et de Séismologie, 15, Luxembourg, 99 pp.

ISIDe Working Group (INGV) (2010). Italian seismological instrumental and parametric database: http:/ / iside.rm. ingvit, last accessed, July 2012.

Locati, M., R. Camassi and M. Stucchi, eds. (2011). DBMI11, the 2011 version of the Italian macroseismic database, Milano, Bologna; http:// emidius.mi.ingv.it/DBMI11 (last accessed, July 2012).

MCS (1930). Scala macrosismica Mercalli-Cancani-Sieberg, In: A. Sieberg (ed.), Geologie der Erdbeben, Handbuch der Geophysic, Tables 2 and 3, Berlin.

Pasolini, C., D. Albarello, P. Gasperini, V. D'Amico and R. Lolli (2008). The attenuation of seismic intensity in Italy, part II: modeling and validation, B. Seismol. Soc. Am., 98, 692-708; doi:10.1785/0120070021.

QUEST-INGV (2012). Sintesi degli effetti del terremoto del 20 maggio $2012\left(\mathrm{M}_{\mathrm{L}}=5.9\right)$ sulle località rilevate dalle squadre di QUEST INGV, Open file report; http: / / quest. ingv.it/images/pdf/quest_report_28maggio_protect.pdf (last accessed September 2012).

Rovida, A., R. Camassi, P. Gasperini and M. Stucchi, eds. (2011). CPTI11, the 2011 version of the parametric catalogue of Italian earthquakes, Milano/Bologna; http:/ / emidius.mi.ingv.it/CPTI (last accessed, July 2012).

\footnotetext{
${ }^{\star}$ Corresponding author: Andrea Tertulliani, Istituto Nazionale di Geofisica e Vulcanologia, Sezione Roma 1, Roma, Italy; email: andrea.tertulliani@ingv.it. 